\title{
A Medium-term Analysis of Wastewater from an Agricultural Area
}

\author{
CARMELIA MARIANA DRAGOMIR BALANICA ${ }^{1}$, AUREL GABRIEL SIMIONESCU², CAMELIA LACRAMIOARA POPA ${ }^{1}$, \\ CEZAR-IONUT BICHESCU ${ }^{1}$, CRISTIAN MUNTENITA ${ }^{1 *}$ \\ ${ }^{1}$ Dunarea de J os University of Galati, 47 Domneasca Str., 800008, Galati, Romania \\ ${ }^{2}$ Constantin Brancoveanu University of Pitesti, Faculty of Management Marketing in Economic Business, 1 Targu din Vale Str., \\ 110040, Pitesti, Romania
}

\begin{abstract}
Nitrate is ordinarily found within the ecosystem, as part of the nitrogen cycle. The anthropogenic inputs have highly increased nitrate loads into ground and surface waters. All these factors have had a drastic impact on aquatic environment, human health and flora and fauna. Hence, the identification of nitrate sources is valuable in conserving water quality and achieving sustainability of the water resources. The present paper aims to present a clearly image of water pollution in South and South Est part of Romania. The dataset for ammonium $\left(\mathrm{NH}_{4}^{+}\right)$, total nitrogen $\left(\mathrm{N}_{\text {tot }}\right)$ and nitrite $\left(\mathrm{NO}_{2}^{-}\right)$was collected from 2013 -2017.
\end{abstract}

Keywords: water pollution; nitrate; human health

High nitrogen concentration in the ecosystem can determine modifications in the natural nitrogen cycle among population, soil, water, and atmosphere [1]. Nitrogen pollution in water can generate severe issues, such as degradation of water quality, eutrophication and probable risk to animal and human health [2].

The probable sources of chemicals contamination of water contain residues from domestic wastewater, different types of industry, pesticide and herbicide runoff from agricultural farmlands [3]. Consequently, a comprehension of water pollution and its management rely upon an elementary study of aquatic system chemistry [4]. The wastewaters depending on the source of origin may contain organic matter, dissolved salts, oils, fats, detergents, chemicals and even heavy metals [5].

Nitrates resulting from agriculture are one of the significant water pollution factors. Nitrates generally exist in insignificant quantities in soil and water, but some quantities are frequently supplemented by farmers. This issue started with intensive agriculture and with the using of fertilizer in order to increase the production volume. The nitrate surplus added to soil penetrate into ground water thus contaminating them $[6,7]$.

The degree of ionization is conditioned on the temperature, the $\mathrm{pH}$, and the concentration of dissolved salts in the water. The environmental cycling of nitrogen depends principally on nitrate, followed by ammonia and the ammonium cation, which predominates. The ammonium cation is less mobile in soil and water compared to ammonia and is involved in the biological processes of nitrogen fixation, mineralization, and nitrification.

The aim of this paper was to determine municipal waste water treatment plant impact on water quality affected by nutrient content to the Danube River basin during the time period of 2013-2017.

\section{Experimental part}

The study area is located in the South and South Est part of Romania. The five analyzed waste water treatment plant (WWTP) are built in cities: Giurgiu, Calarasi, Braila, Galati and Tulcea, are situated on the bank of the Danube river. The land use is principally agricultural consisting of corn, wheat paddies in the lowlands, growing vegetable in greenhouses and vegetable crops and fruit orchards. Samples were collected from five sites on the Danube River.
The dataset containing ammonium $\left(\mathrm{NH}_{4}^{+}\right)$, nitrite $\left(\mathrm{NO}_{2}^{-}\right)$and total nitrogen ( $\mathrm{N}_{\text {tot }}$ ) was measured from 2013 to 2017.

National procedure of monitoring the quality of surface waters and numerous discharges of wastewaters into surface water necessitates an analytical analysis of nitrogen concentrations in various forms: ammonia, nitrate, nitrite, organic nitrogen, Kejdhal nitrogen and total nitrogen (TN). In WWTP laboratories, the streamline of the analytical mechanism relates to the application of the safe analytical proceeding, and competent cost reduction of the analysis.

\section{Determination of ammonium content (SR ISO 7150-1)}

The technique used is manual spectrophotometric procedure for the determination of ammonium in water directly applicable drinking water and most raw and waste waters. It can cause an ammoniacal nitrogen concentration of up to $\rho=1 \mathrm{mg} / \mathrm{L}(1.288 \mathrm{mg} / \mathrm{I} \mathrm{NH} 4)$ utilizing the sample not exceeding $40 \mathrm{~mL}$. The reaction of chloramine with sodium salicylate occur at $\mathrm{pH} 12.6$ in the presence of sodium nitroprusside. Quantitatively are obtained the chloramines present in the sample. Sodium citrate is added to mask interfering time cations, principally calcium and magnesium [8].

\section{Determination of nitrite content (SR EN 26777:2002)}

The technique used is molecular absorption spectrometric technique for the analysis of nitrite in drinking water, raw water and wastewater. The method is adequate to content of up to $0.25 \mathrm{mg} / \mathrm{L} \mathrm{N}(0.8285 \mathrm{mg} / \mathrm{L}$ $\mathrm{NO}_{2}$ ) utilizing a sample volume of less than $40 \mathrm{ml}$. The detection limit of the technique using cells having path length of $40 \mathrm{~mm}$ and a $40 \mathrm{~mL}$ sample volume is in the range from 0.001 to $0.002 \mathrm{mg} / \mathrm{L} \mathrm{N}(0.0033$ to $0.0066 \mathrm{mg} /$ ( $\mathrm{NO}_{2}$ ). For cells with $10 \mathrm{~mm}$ optical path, and a sample volume of $40 \mathrm{ml}$ detection limit is in the range from 0.0132 to $0.0264 \mathrm{mg} / \mathrm{L} \mathrm{NO}$ ) ( $1 \mathrm{mg} / \mathrm{L} \mathrm{N}=3.29 \mathrm{mg} / \mathrm{L} \mathrm{NO}_{2}$ ). Nitrite ions in the highly acidic medium $\mathrm{pH}=1.9$ is reacted with the reagent 4-amino benzene sulfonamides in the presence of orthophosphoric acid to constitute a diazonium salt that completes a red complex of N-(1-naphthyl) ethylenediamine dihydrochloride. It has the absorbance at $540 \mathrm{~nm}[9]$.

\footnotetext{
* email: cristian.muntenita@ugal.ro
} 
Determination of nitrate content (SR ISO 7890-3: 2000)

The technique for analyzing the nitrate ion in water is appropriate to examine samples of raw water. The procedure is adequate to a nitrogen content of up to 0.2 $\mathrm{mg} / \mathrm{L} \mathrm{N}\left(0.88 \mathrm{mg} / \mathrm{L} \mathrm{NO}_{3}\right)$ using the sample volume max. $25 \mathrm{~mL}$. The technique contained in analyzing the spectrophotometric absorbance of the yellow compound raised by the reaction of sulfosalicylic acid (resulted by the addition of sodium salicylate in the sample and sulfuric acid) to nitrate, followed by analysis with alkaline compound. Ethylenediaminetetraacetic acid disodium salt is added to the alkaline solution to avoid precipitation of calcium and magnesium salts [10].

The Spline interpolation from ArcGIS geo-statistical module was used to geta graphical description of pollutants distribution. The Spline tool utilize an interpolation technique that estimates values applying a mathematical function that minimizes general surface curvature, resulting in a smooth surface that passes exactly through the input points [11].

\section{Results and discussions}

A dataset collected between 2013 and 2017 was used to analyses the amount of total nitrogen $\left(\mathrm{N}_{\text {tot }}\right)$, ammonium $\left(\mathrm{NH}_{4}^{+}\right)$and nitrite $\left(\mathrm{NO}_{2}^{-}\right)$in Danube river basin. The yearly average was used to present the difference between wastewater quality before to be purified in municipal WWTP (inflow) and characteristics after was treated, before to discharge into the Danube. All of ammonium data were less than the limits allowed by legislation. From figure 1 it is noted that the higher value of inflow ammonium $\left(\mathrm{NH}_{4}^{+}\right)$was $50.98 \mathrm{mg} / \mathrm{dm}^{3}$ from Braila while $0.96 \mathrm{mg} / \mathrm{dm}^{3}$ was the outflow effluent. The highest nitrite $\left(\mathrm{NO}_{2}{ }^{-}\right)$inflow average was $2.96 \mathrm{mg} / \mathrm{dm}^{3}$ from Giurgiu comparing with $0.59 \mathrm{mg} / \mathrm{dm}^{3}$ the outflow average. The total nitrogen $\left(\mathrm{N}_{\text {to }}\right)$ for inflow ranges from $0.56 \mathrm{mg} / \mathrm{dm}^{3}$ in Calarasi to $2.96 \mathrm{mg} / \mathrm{dm}^{3}$ in Giurgiu while the outflow average varies from $0.21 \mathrm{mg} / \mathrm{dm}^{3}$ in Braila to $0.91 \mathrm{mg} / \mathrm{dm}^{3}$ in Galati.

In order to get a visual image of ammonium $\left(\mathrm{NH}_{4}^{+}\right)$, nitrite $\left(\mathrm{NO}_{2}^{-}\right)$and total nitrogen $\left(\mathrm{N}_{\text {tot }}\right)$ dispersion it was created a five-year map for each analyzed item. The spatial description of $\mathrm{NH}^{+}$is useful to have an overview of the entire region and to establish with good accuracy the sources of pollution.

The lowest amount of Ammonium $\left(\mathrm{NH}_{+}^{+}\right.$) for period 2013-2017, was measured in Tulcea $23.16 \mathrm{mg} / \mathrm{dm}^{3}$ wastewater before it is treated in the treatment plant and $0.96 \mathrm{mg} / \mathrm{dm}^{3}$ from Braila, represents the five years average for purified water (fig. 2) A larger amount of $\mathrm{NH}_{4}^{+}$can be observed between Calarasi and Braila counties, and this concentration is reduced after the wastewater treatment in the Braila WWTP and after the treatment from WWTP Galati. The analyzed area in this study is an agricultural one and it is very obvious that ammonia is used in fertilizer and animal feed production.

The largest amount of $\mathrm{N}_{\text {tot }}$ is loaded in Giurgiu, 60.63 $\mathrm{mg} / \mathrm{dm}^{3}$ and after wastewater treatment in Giurgiu WWTP, the concentration is $10.23 \mathrm{mg} / \mathrm{dm}^{3}$. A visual analysis indicates higher values of $\mathrm{N}_{\text {to }}$ before treatment in WWTP Braila. The five years average of the difference between the inflow and outflow is $36.52 \mathrm{mg} / \mathrm{dm}^{3}$, which highlights
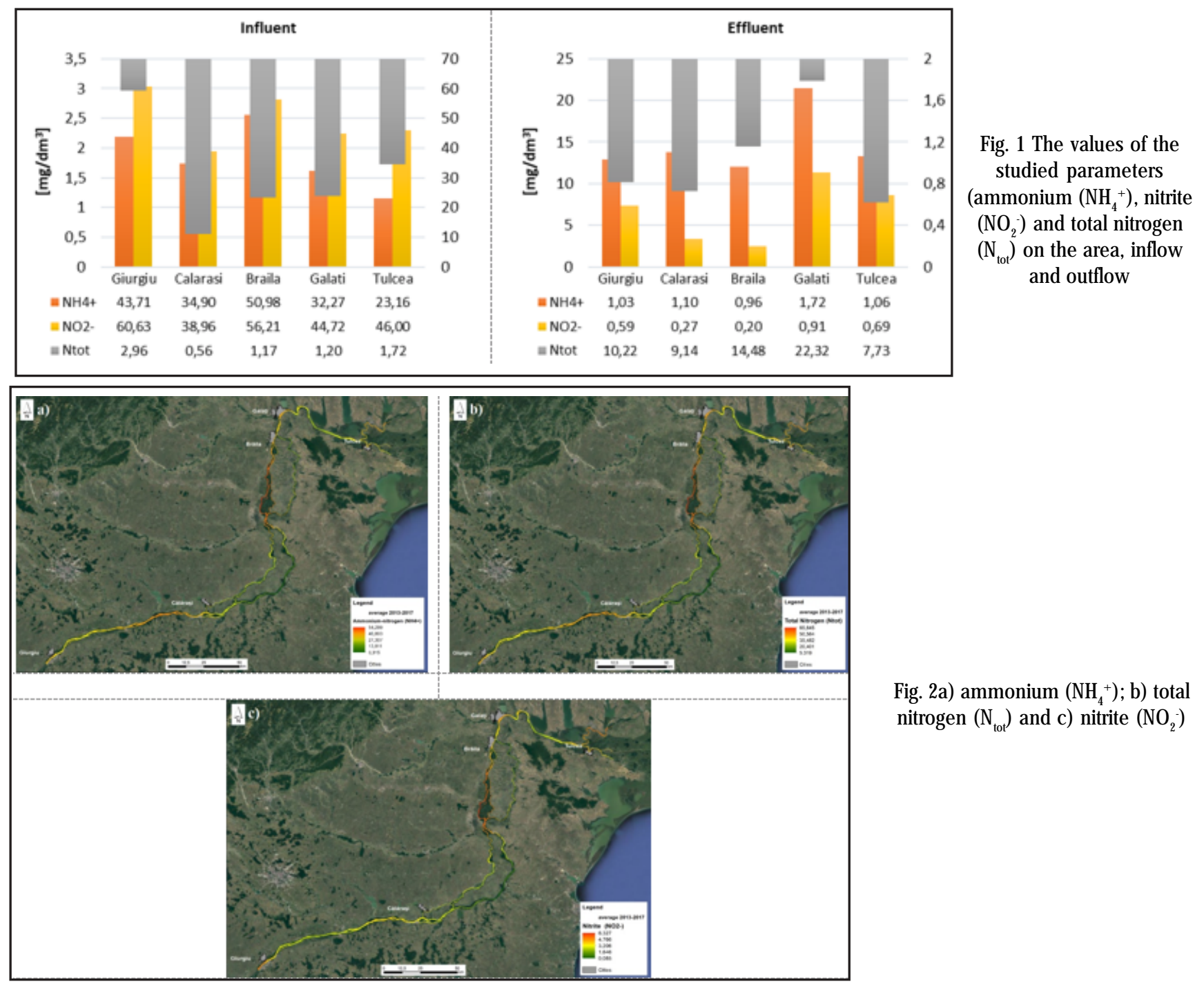

Fig. 2a) ammonium $\left(\mathrm{NH}_{4}^{+}\right)$; b) total nitrogen $\left(\mathrm{N}_{\text {tot }}\right)$ and $\mathrm{C}$ ) nitrite $\left(\mathrm{NO}_{2}{ }^{-}\right)$ 
the need for water treatment before being discharged into the Danube.

The average value of nitrite nitrogen $\left(\mathrm{NO}_{2}\right)^{-}$) during the monitored period was $2.68 \mathrm{mg} / \mathrm{dm}^{3}$ at the inflow to the WWTP and $0.53 \mathrm{mg} / \mathrm{dm}^{3}$ at the outflow from the WWTP.

High values of $\mathrm{NO}_{2}^{-}$are especially noticeable before WWTP Giurgiu $2.96 \mathrm{mg} / \mathrm{dm}^{3}$ and $1.72 \mathrm{mg} / \mathrm{dm}^{3}$ before WWTP Tulcea.

The wastewater that is rich in ammonia nitrogen impede the natural nitrification, determine water hypoxia, result in fish intoxication, decrease the water purification efficiency, and finally alter the water environment.

\section{Conclusions}

Inland water pollution problem with repercussions on both the drinking water supply of large urban areas and on irrigation and biodiversity is the current moment of the first interest. In these conditions the required parameters functioning sewage treatment plants is a very important objective. There is an accelerated process of moving from disposal directly to the emissary to a series of increasingly complex and integrated wastewater treatment. This also from the perspective of increasingly restrictive environmental regulations. In order to establish an adequate waste management system, appropriate recognition and characterization of the influent entering a wastewater treatment plant is imperative.
All the results indicate that to reduce Total Nitrogen $\left(\mathrm{N}_{\text {tot }}\right)$ loads to river Danube basin from point sources small WWTP (PE < 10000) have to be targeted. In Romania, poorly purified waste water has been identified as one of the main eutrophication causes in the Black Sea region.

\section{References}

1. OBAJA, D., MACE, S., COSTA, J., SANS, C., MATA-ALVAREZ, J., Bioresour. Technol, 87, 103-111, 2003.

2. KHAN, M., MOHAMMAD, F., Eutrophication: Challenges and Solutions. In: Ansari A., Gill S. (eds) Eutrophication: Causes, Consequences and Control. Springer, Dordrecht. (2014).

3. BAKER, L.A.,ACS Advances in Chemistry Series 237, American Chemical Society, DC, 2005.

4. ARUNDEL, J., Blackwell Science Ltd., Editional Offices, Oxford, UK, 2000.

5. ROMANESCU, G., SANDU, I., STOLERIU, C., SANDU, I.-G., Rev Chim.(Bucharest), 65, no. 3, 2014, p. 344

6. ARUNDEL, J., Blackwell Science Ltd., Editional Offices, Oxford, UK, 2000.

7. DUMITRACHE, F., DIACU, E., Rev Chim. (Bucharest), 61, no. 3, p. $328,2010$.

8. *** SR EN 26777:2002 - Determination of nitrite content 9. *** SR ISO 7150-1:2001 - Determination of ammonium content

10. *** SR ISO 7890-3:2000 - Determination of nitrate content

11. *** ESRI (Environmental Systems Research Institute). ArcGIS 10.3.1 for Desktop Help, 2015.

$\overline{\text { Manuscript received: } 9.11 .2018}$ 